\title{
Economic Citizenship: Is It Worthy Investment?
}

\section{Mustafa Şeref AKIN}

\section{Ekonomik Vatandaşlık: Yatırıma Değer mi?}

\begin{tabular}{l} 
ARTICLE INFO \\
\hline Article History: \\
Date Submitted: 08.02.2019 \\
Date Accepted: 15.05 .2019 \\
\hline JEL Classification: \\
F21 \\
F12 \\
F6 \\
Keywords: \\
Economic Citizenship, \\
Second Citizenship, \\
Visa-free Countries, \\
Investment.
\end{tabular}

\begin{abstract}
The selling of economic citizenship is expanding and gradually becoming an industry. This paper weighs the cost-benefit analysis of economic citizenship in three aspects, visa-free country (VFC), marginal contribution and investment threshold aspects. The return on investment for the visa-free access is moderate, around $1-2 \%$ for a frequent traveler family and $0.2-0.5 \%$ for a frequent traveler single. Based on these analyses, unless an investor is a very frequent traveler, investment by citizenship programs are not feasible from visa-free country's aspect. However, the benefits of acquiring economic citizenship from an EU country can compensate the low return on visa-free access. Under the marginal analysis, we eliminated the redundancy among passports and we calculated the additional benefits of an extra passport. This shows that acquiring a passport from developing countries is not meaningful for the citizens from developed countries. Under the investment threshold analysis, we demonstrated the minimum investment requirement. Some countries might be more advantageous for the return on investment along with citizenship, but they set the investment threshold so high that countries with donation might be more feasible.
\end{abstract}

1 Mustafa Şeref AKIN, Prof. Dr. Erzincan Binali Yıldırım Üniversitesi, IIBF, mustafa.akin@erzincan.edu.tr 


\section{Özet}

Bir mali Ekonomik vatandaşlığın satışı genişliyor ve yavaş yavaş bir endüstri haline geliyor. Bu makale, ekonomik vatandaşlığın maliyet-fayda analizini üç açıdan: vizesiz giriş, marjinal katkı ve yatırım eşiği açısından ele almaktadır. Vizesiz erişim için ekonomik vatandaşlık yatırım getirisi düşük, sık seyahat eden bir gezgin için \%0,2- \%0,5 arasında ve sık seyahat eden bir aile için \%1-\%2'dir. Bu analizler altında, bir yatırımcı sık seyahat etmedikçe, vizesiz giriş açısından akılcı bir yatırım değil. Bununla birlikte, bir AB ülkesinden ekonomik vatandaşlığın elde edilmesinin faydaları, vizesiz erişimin düşük getirisini telafi edebilir. Marjinal analiz altında ek bir pasaportun ek faydaları hesaplandı ki gelişmekte olan ülkelerden pasaport almanın gelişmiş ülkelerin vatandaşları için anlamlı olmadığını göstermektedir. Yatırım eşiği analizi kapsamında, minimum yatırım gereksinimleri incelendi. Bazı ülkeler, vatandaşlık ile birlikte yatırımın geri dönüşü için daha avantajlı olabilirler, ancak minimum yatırım barajını o kadar yüksek tutarlar ki, bağış yapılan ülkeler daha tercih edilebilir.

\section{Introduction: Return On Investment}

This article examines the return on investment of economic citizenship (Xin, et, al., 2015). Citizenship by investment or economic citizenship is a well-defined process whereby wealthy individuals can obtain second citizenship quickly in exchange for an investment or donation. It is generally of interest to ultra-high net worth (UHNW) clients. The tax, asset protection, travel freedom and privacy benefits for such clients are normally substantial and almost immediate. Those who are interested in investing and obtaining economic citizenship have a pressing need to have another passport for tax, business, or travel reasons (Brinker and Dalson, 2008: 21). Having dual citizenship (or even multiple citizenships) gives you the freedom to travel and invest; that having one citizenship alone cannot grant (Caribbean and Land Property, 2018: 2).

We calculate the return on citizenship investment based on three analyses: visa-free return, marginal contribution and investment threshold. Under the marginal contribution analysis, we eliminate the redundancy among passports, and we calculate the additional benefits of a passport. Under the investment threshold analysis, we compare the minimum investment 
requirements for citizenship. Based on these analyses, unless an investor is a very frequent traveler, investment by citizenship programs are not feasible from visa-free country's aspect.

The economic literature on citizenship is linked to immigration for a higher return. Education, culture, occupation, demographic characteristics and income opportunities are the main dominant factors for acquiring citizenship (Kelley and McAllister, 1982: 430; Portes and Mozo, 1985: 60; Bevelander, 2000: 118, Yang, 1994: 470, Barkan and Khokhlov, 1980: 160, Portes and Curtis, 1987: 355, Mazzolari, 2009: 170; DeVoretz and Pivnenko (2004). Moreover, the current economic literature on naturalization considers passport as a free public good (DeVoretz and Pivnenko, 2004). However, the differences among citizenship opportunities and passport qualities in the world in terms of visa-free access, taxation policy and business opportunities lead an economic value of the acquisition of the economic citizenship (Arton Capital, 2018). However, the demand and supply of the economic citizenship market is determined by travel, business, financial and tax opportunities rather than higher wages (Henderson, 2018: 10-20). An investor does not reside but rather seeks for opportunities of the second passport (Henderson, 2017: 1). For example, an investor acquires the Bulgarian passport not for living in Bulgaria but for living in another EU country (i.e. France).

\subsection{Historical Development}

Historically, the Caribbean countries like Belize, Dominica, Grenada, St. Kitts \& Nevis, and St. Vincent and the Grenadines offer citizenship programs since they need capital and don't have many other resources that they can use to attract foreign direct investment. The St. Kitts \& Nevis program originated in 1984 (Constitution Part II, Section 3, 5) of the Citizenship Act is the oldest of the citizenship by investment. The sugar diversification fund program (SDFP) is a viable means of recovering the decline of sugar revenue, of developing the country's infrastructure, agriculture, tourism and public budgeting. All Caribbean countries face similar constraints. To restructure and overcome the debt and to support the local economy, these countries introduced a citizenship-by-investment program (St. Kitts and Nevis Program, 2018: $1)$.

Selling citizenship is a very lucrative business. For example, in 2015, St. Kitts and Nevis gave the budget surplus of about $\$ 222$ million. The Surplus was derived from the revenue $\$ 733$ 
million and expenditure of $\$ 511$ million. Non-Tax Revenue is the main contributor to a favorable result. Fees from the Citizenship by Investment Program collected 307 million USD revenue for 2015 by 42.3 percent of the total government budget.

In the Caribbean, economic citizenship becomes an industry and is popular among wealthy classes. St Kitts and Nevis was awarded as the best-performing nation by Professional Wealth Magazine's CBI Index (Professional Wealth Magazine, 2018: 5).

Due to the intense need for capital needs and government budget deficit, Dominica, St. Lucia, Antigua and Barbuda entered into citizenship market. However, the growth in economic citizenship sell led a big macroeconomic risk of sudden-stop capital inflow due to competition (Xin et.,al., 2015: 2).

Many countries from Vanuatu to the U.S.A. offered citizenship scheme or investment residency and most were being created with similar programs proliferating from the Caribbean programs (Houlder, 2016: 1). Foreigners can buy legal status to live, work and invest in several countries. Perhaps more importantly, they buy access to visa-free travel to countries around the world through citizenship.

\subsection{Price Determination}

Citizenship is somewhat of a commodity. The price of citizenship determines the supply and demand. Therefore, the economic citizenship price rises and falls since it is created in 1984 by St. Kitts and Nevis (St. Kitts and Nevis Citizenship Program, 2018: 4).

The number of second citizenship programs has recently surged (Xin, et.al., 2015). There are approximately 5000 citizenships sold each year. China is the predominant source of applicants, making up about 70\%, but citizens like Russia, Turkey, Vietnam, India and Brazil have been sources of growth in the past few years (csglobalpartners, 2018: 5; Houlder, 2016: 3).

\subsection{Residency by Investment and Citizenship by Investment}

Residency by investment is not the same as citizenship by investment (economic citizenship). Some residency by investment can convert to citizenship while some do not. Residency visa programs like those in the U.S., the U.K., Portugal and Spain will eventually yield a second passport, but it will take at least six years. Citizenship by investment via residency might 
be the same as citizenship by investment if there may not be necessary for the applicant actually to live there, full time. However, large English-speaking countries such as the U.S.A., U.K. and New Zealand require applicants to live full time and therefore their citizenship by investment via residency program is not an economic citizenship (Arton Capital, 2018: 8; US Immigration Office, 2018: 2).

These countries are expecting that people are willing to live in their country as an immigrant and become subject to tax. However, citizenship by investment via residency granted by Portugal offers citizenship in 6 years with a very short period of residency - 2 weeks a year. Portugal might be considered an economic citizenship since many advantages of working in Portugal and visiting EU (European Union) is granted at the beginning of the program. After 5 years, obtaining of Portuguese permanent residency allows the full benefits of EU.

Hence, the important attitude distinction between economic citizenship (i.e. Caribbean program) and naturalization (i.e. the U.S.) is that most of the economic citizenship clients do not visit and live in the country they invest in citizenship. Many people pursue a second passport as an insurance policy (Beck, 2017: 13). We may call economic citizenship as a citizenship insurance.

\section{Economic Analysis of Economic Citizenship}

\subsection{Data}

There are many economic citizenship/residency programs around the world that provide citizenship in exchange for substantial financial transfers or payments. Tables 1 and 2 in annex represent the data structure regarding the cost for a family of four and single investors. There are varieties of schemes for each country.

We focus on donation or cash related choices (i.e. purchasing bonds) rather than real estate investment for the Caribbean. Since there are many obstacles and additional (hidden) fees involved in real estate investment. In addition, forced real estate purchase drive the market up and leads to paying higher prices. The idea of recovering their investment is obviously very attractive. However, people fall into sunk cost effect in the Caribbean case (Dhami, 2017). They are upset by paying donation fees which are not covered. However, the real estate offered 
through these Caribbean programs is very low quality (Strauss, 2012). Real estate developers know that a buyer should buy from the "approved project" and therefore raise the prices artificially. Additionally, the government raises the state fees when the applicant opts for the approved real investment options. It is a fact that the real estate investment creates economic activities, but the government cannot receive direct revenue and therefore, charge some additional fees. Purchasing the real estate or investment in a business is not about the quality (number of visa-free countries) of passport but economic conditions. In the case of the Caribbean real estate options, there is no supply and demand to create a depth (easy sold and purchased due to high volume). The supply is being out-stripped by a bunch of approved developers. Additionally, one doesn't know about developers and projects. So, the quality of real estate is an issue. Therefore, under the most economic citizenship programs, real estate isn't attractive and overpriced. There is practically no local real estate market in the Caribbean. Therefore, one has to sell with a large discount (Elma Global, 2018: 3).

At donation, the full cost is apparent. We calculate the opportunity cost at zero-coupon government bond investment to compare donation costs. We use 5\% as an opportunity cost of an investment.

In the real estate investment, the cost is calculated as follows: (opportunity cost of investment $+\operatorname{tax}) *($ years of holding requirement $)$. We subtract the cost from the return on investment since there is a yield on real estate (i.e., rent). For instance, under the Greek scheme, 250,000 EURO property acquisition is not sufficient, and one applicant should wait for 6 years and hence the opportunity cost is $(250,000$ Euro $) *(5 \%+1 \%) *(6$ years $) .1 \%$ is added due to property tax. Certainly, one may acquire a rent revenue from the real estate. In this case, we consider $3 \%$ as a return in Europe. Due to these real estate programs, real estate prices have been augmented and therefore neglected the capital gain (Henderson, 2018).

\subsection{Government Fees}

Government fees can consist of a big portion and sometimes as high as the investment amount. These fees can be taken in different names and be added under one name as government fees.

Countries may charge high fees to process one's residency and citizenship application. Therefore, those fees should be taken account of. Sometimes, governments manipulate the cost 
of application by reducing the investment/donation cost while raising government fees. For instance, Antigua and Barbuda reduced the application fee from 200.000 to 100.000 USD for a family of four but raises the government fees from 7500 USD to 33,500 USD (Henderson, 2018). Moreover, governments exacerbate the fees under different names such as value added tax on properties, processing, background checking, and certificate issues fees.

\subsection{Professional Services Fee}

Governments delegate the economic citizenship program to "approved agencies". At the professional service, the wealthier the country, the more the lawyers and agencies will charge. We assume 10,000 USD in general.

\subsection{Visa-free Index}

The most important factor in the value of a passport is the travel opportunities. We derive the list of visa-free countries (VFC) from the passport index ranking (Passportindex.com, 2018). There are 199 countries ranked based on visa-free access and the highest power is Singapore and South Korea with 163 VFC and the lowest is Afghanistan with 27 VFC.

\section{Visa-free Analysis}

We divide countries in terms of the EU, Caribbean and others because the EU citizenship might be more expensive due to the right to live in Europe considered to be of high value, the citizenship market of the Caribbean becomes an industry and the category of others show a lot of varieties across the world.

\subsection{Investment on Visa-free Return}

The general approach for the return on investment is the calculation of economic saving visa-free travel and the cost of acquisition of passport. So, the return on investment can be calculated:

Return on Visa-free: Economic saving visa-free travel/Cost of Acquisition of Passport

The economic saving visa travel consists of the cost of visa and bureaucratic items (preparation and collecting the necessary documents and waiting for an appointment and issuing of the visa) (table 3). 
A Schengen visa for 3 months is 60 EURO for adult, 30 EURO for children, the nonreversible application cost health care insurance, 30 EURO and professional service agency fee, 30 EURO) (https://www.schengenvisainfo.com/schengen-visa-fee/, https://www.axaschengen.com/en/price-travel-insurance and http://www.hmcvize.com). So, 120 EURO for adults and 60 Euro for children. EU countries also charge 60 EURO for a transit passenger.

The U.S.A. visa fee from 1 month to the 10 -year issues is 220 USD (half for children) which includes 160 USD visa charge and 60USD for a professional service.

So, for a family of four without considering bureaucratic cumbersomeness is about 500 USD for the Schengen and the U.S. visas (with children reduction).

Table 3. Return on Economic Citizenship Investment in terms of Visa cost (USD)

\begin{tabular}{|c|c|c|c|c|}
\hline USD & $\begin{array}{r}\text { Once a year- } \\
\text { family } \\
\text { (infrequent } \\
\text { traveler) }\end{array}$ & $\begin{array}{r}\text { Year } \\
\text { coverage- } \\
\text { family } \\
\text { (frequent } \\
\text { traveler) }\end{array}$ & $\begin{array}{r}\text { Once a year- } \\
\text { single } \\
\text { (infrequent } \\
\text { traveler) }\end{array}$ & $\begin{array}{r}\text { Year } \\
\text { coverage- } \\
\text { single } \\
\text { (frequent } \\
\text { traveler) }\end{array}$ \\
\hline Visa Cost-Normal & 500 USD & 2000 & 125 & 500 \\
\hline Visa Cost-Urgent & 850 & 3400 & 225 & 900 \\
\hline $\begin{array}{l}\text { Passport Acquisition Cost for Caribbean } \\
\text { (average) }\end{array}$ & 155,000 & 150,000 & 117,500 & 117,500 \\
\hline $\begin{array}{l}\text { Passport Acquisition Cost for European } \\
\text { (average) }\end{array}$ & 316,250 & 316,250 & 260,274 & 260,274 \\
\hline $\begin{array}{l}\text { Passport Acquisiton Lowest Cost for } \\
\text { European }\end{array}$ & 104,075 & 104,075 & 104,075 & 104,075 \\
\hline $\begin{array}{l}\text { Return on Caribbean for VF-normal } \\
\text { (column 1/column 3) }\end{array}$ & $\begin{array}{r}0,3 \% \\
(500 / 155000)\end{array}$ & $\begin{array}{r}1,3 \% \\
(2000 / 155,000)\end{array}$ & $\begin{array}{r}0,2 \% \\
(125 / 117,500)\end{array}$ & $\begin{array}{r}0,3 \% \\
(500 / 117,500)\end{array}$ \\
\hline $\begin{array}{l}\text { Return on Caribbean for VF-Urgent } \\
\text { (column 2/column 3) }\end{array}$ & $\begin{array}{r}0,5 \% \\
(850 / 155,000)\end{array}$ & $(3400 / 155,000)$ & $\begin{array}{r}0,2 \% \\
(225 / 117,500)\end{array}$ & $\begin{array}{r}0,6 \% \\
(900 / 117,500)\end{array}$ \\
\hline
\end{tabular}




\begin{tabular}{|c|c|c|c|c|}
\hline $\begin{array}{l}\text { Return on European for visa-normal } \\
\text { (column 1/column 4) }\end{array}$ & $\begin{array}{r}0,2 \% \\
(500 / 316,250)\end{array}$ & $(2000 / 316,250)$ & $\begin{array}{r}0,04 \%(125 / \\
260,274)\end{array}$ & $\begin{array}{r}0,19 \% \\
(500 / 260,274)\end{array}$ \\
\hline $\begin{array}{l}\text { Return on European for visa-Urgent } \\
\text { (column 2/column 4) }\end{array}$ & $\begin{array}{r}0,3 \% \\
(850 / 316,250)\end{array}$ & $\begin{array}{r}1,1 \% \\
(3400 / 316,250)\end{array}$ & $\begin{array}{r}0,1 \% \\
(225 / 316,250)\end{array}$ & $\begin{array}{r}0,3 \% \\
(900 / 316,250)\end{array}$ \\
\hline $\begin{array}{l}\text { Return on lowest cost European for visa } \\
\text { normal (column 1/column 5) }\end{array}$ & $\begin{array}{r}0,5 \% \\
(500 / 104,075)\end{array}$ & $\begin{array}{r}1,9 \% \\
(2000 / 104,075)\end{array}$ & $\begin{array}{r}0,1 \% \\
(125 / 104,075)\end{array}$ & $\begin{array}{r}0,5 \% \\
(500 / 104,075)\end{array}$ \\
\hline $\begin{array}{l}\text { Return on lowest cost European for visa } \\
\text { urgent (column 2/column 5) }\end{array}$ & $\begin{array}{r}0,8 \% \\
(850 / 104,075\end{array}$ & $(3400 / 104,075)$ & $\begin{array}{r}0,2 \% \\
(225 / 104,075)\end{array}$ & $(900 / 104,075)$ \\
\hline
\end{tabular}

Source: Arton Capital (2017), GOCCP (2018), Goldenvisas (2018), Goldencitizenship (2018), author's calculations.

How often a person or family needs to get a visa? The Schengen visa is generally issued for 90 days. If a family of four wants to cover a total year, they need to get it 4 times and pay about 2000 USD for Schengen. However, non-European and non-Schengen countries (i.e. the U.S., the U.K.) are not covered. On the other hand, whole-year-coverage-need might not be the economic but psychological: Stress-free process of getting visa and being free to travel whenever and wherever. Indeed, we may assume this hypothetical family sometimes travel to Schengen area and sometimes to another region as frequent travelers. So, two times to Schengen area, one-time 6 big English countries and one-time to other countries application can be meaningful for the analysis. Hence, our 4-time visa request (2000 USD) may hold for the entire world: Schengen/Six big English countries (U.S., U.K., Ireland, Australia, Canada, New Zealand) /others areas.

What might be the cost of waiting for the appointment of the visa interview? For the Schengen area, the urgent application fee charges an extra for 70 Euro (85 USD) for each. So, our hypothetical family for the infrequent traveler needs to pay 850USD and for the frequent traveler needs to pay 3400 USD.

The cost of Antigua and Barbuda (the lowest price for a family for a Caribbean economic citizenship) is 155,000 and yearly the total economic cost of visa is $2000-3400$ USD 
(based on emergency) for a whole year, so the return of the investment for a family is $0.3 \%$ $(500 / 155,000)$ for the infrequent traveler (once a year), $1,3 \%$ for frequent traveler (2000/155,000) (for whole year- normal visa). It is a moderate return comparing to the US 30 year government bond (3\%) (Bloomberg, 2019). There is slight improvement for urgent visa fee for the infrequent traveler family $(0.5 \%)$ but the frequent travelers $(2.1 \%)$. In this scenario, the better return depends on how likely a family needs to travel. However, in any case, the return is not high.

The cost of St. Lucia (lowest price for a single for a Caribbean passport) for a single is 117,500 USD so, if single needs a whole-year-coverage for the infrequent, the return of investment is about $0.2 \%$, a very low return. Similarly, if this investor makes several trips a year, the return will only be 0,3-0,6\%, depends on urgency.

The average EU (potential EU passports) is costlier than the Caribbean, almost double. Hence the return on investment is cutting by half. The return on citizenship investment is $0.2 \%$ for the infrequent traveler and 1\% for the frequent travelers. However, if a smart investor picks to the lowest price tag among the EU countries, Portugal, the cost falls behind the ones of the Caribbean. The return jumps to $3.3 \%$ for the family-frequent traveler and 0,9\% for the single frequent-traveler.

The results show that the return on passport investment depends on the frequency of travel and is low. Based on our economic analysis, the individual decision should be given regarding necessity rather than potentials.

\subsubsection{Other Consideration At Visa Application and EU Citizenship}

Our above analysis did not consider the rejection, time inconsistency, single-entry and location risks during the application.

In the visa application, there is also a risk of rejection. The rejection rate of Schengen area is around 10\%. For example, between 2015-2017, the application to Schengen visa from Turkey augmented by $8 \%$ but rejection has increased by $37.2 \%$. The total application from Turkey is 971,710 (right after Chinese and Russian citizens), and 63.122 applications are rejected $(6.5 \%)$ (Etios, 2018). The total Schengen application around the world is 16,155,613 (Etias.com, 2018). Moreover, the visa payment fee is non-refundable. 
Another risk is time inconsistency and multiple-entry permission. One may expect to receive 3 months' visa, but the consulates may grant a 30-day visa. It might be one-entry rather than multiple entries, so, one may not leave the Schengen area to non-Schengen area for conducting business and return to the same area with the same visa.

Another problem is location dependency. The consulate in another territory cannot understand the document of your local language, i.e. the applicant is Chinese and wants to apply for the Schengen visa from Cambodia. So, there is one choice. He is obligated to return to China and apply for the Schengen visa and continues to travel towards the Schengen area.

What about the return of investment for EU passport such as Malta, Portugal, Bulgaria, Greece and candidate countries such as Montenegro and Serbia as a EU citizen besides freedom of travel? The issue of EU passport should be differently treated than a Caribbean passport due to EU citizenship. This passport allows an investor to live in the most developed countries such as Germany and France, and in areas of new investment opportunities such as Latvia and Romania or get free of charge world-class education in Netherland and Denmark. Additionally, Portuguese and Greek passports allow visa-free access to the 6 big English-speaking countries (among the EU economic citizenship, the US only requires the visa for Cyprus and Bulgarian citizens). Besides, EU citizens may benefit from many special treatments from major European non-EU countries (i.e., Switzerland, Norway and U.K.).

How can we incorporate all these benefits? If Germany and France sell their citizenship, how much price tag will be on it? We don't know but the Maltese economic citizenship priced as the 12th strongest passport may give a clue. 1 million USD worth Maltese passport price might be a good indicator for Germany and France as the third and fourth most powerful in the world passport ranking (table 1). Bulgarian and Portuguese citizenship may allow to have the same rights as the German and the French citizens. From this perspective, these countries fees may be a bargain comparing to Malta (EU citizenship and visa-free to 6 big English-speaking countries). Without the necessity of acquiring a property, the Serbian donation program cost 230,500 USD and covers a very similar number of countries as a Caribbean passport.

Is it worthy to pay for a Serbian passport an extra 75,500 USD of a Caribbean passport (regarding Antigua and Barbuda- 155,000 USD price tag) with a full EU citizenship (table 1 
and 2). EU carry many advantages such as higher salary, free education, and subsidized loan that will cover its costs. We consider 75,500 USD worthy for an EU citizenship.

\subsection{Other Countries’ Return}

Regarding other countries' category, the investment amounts vary from 38,000 USD from Cambodia and 250,000 USD from Quebec/Canada. If we consider 3400 USD as the visa fee for a family as a frequent traveler, then the return on investment is $0,2 \%$ for Canada and the U.S. since passports such as Cambodia, Turkey and Jordan do not solve the visa problem. The return is moderate like Caribbean and EU.

However, neither Canada nor the USA give opportunities to have a passport immediately and therefore the benefits of visa-free travel comes after 4 and 7 years for Canada and the USA, respectively. In the case of Portugal and Bulgaria, the permanent residency status gives opportunities for visa-free access to EU countries with a very short residency duration. We may expect the fee to rise in the future for Portugal and Bulgaria (while we are writing this article, Bulgaria raises its application fee at May 1, 2018) (Arton Capital Newsletter, 2018).

Vanuatu as a similar position to Caribbean islands (visa-free access to the Schengen area), its citizenship price, 245,000 USD, is already higher than the Caribbean. Why may one need to pay $50 \%$ for a similar product? Based on our analysis, Vanuatu needs to reduce their application fees.

\section{Marginal Analysis}

Another way of analysis is to consider the marginal cost of investment in economic citizenship which means that how much we improve through passport acquisition and what the cost is for additional benefits. There are many duplications of visa among passport for visa-free access (table 4). 
Table 4. Marginal Analysis- Visa Improvement on Average

\begin{tabular}{|c|c|c|c|c|}
\hline & $\begin{array}{l}\text { Current \# } \\
\text { countries }\end{array}$ & $\begin{array}{c}\text { Marginal } \\
\text { improvement \# }\end{array}$ & Countries & Cost per country \\
\hline $\begin{array}{l}\text { Developed countries } \\
\text { Marginal developing } \\
\text { countries }\end{array}$ & 150 & 7 & $\begin{array}{c}\text { Some examples: Russia, } \\
\text { Azerbaijan, Iran, Iraq, } \\
\text { Libya, Mongolia, Sudan, } \\
\text { Uzbekistan }\end{array}$ & $\begin{array}{c}150,000 / 7=21,500 \\
\text { USD }\end{array}$ \\
\hline $\begin{array}{l}\text { Developing countries } \\
\text { marginal developed } \\
\text { countries }\end{array}$ & 80 & 70 & $\begin{array}{l}\text { all Europe, Schengen area } \\
\text { and big English countries - } \\
\text { USA, Canada, Australia, } \\
\text { New Zealand and Ireland). }\end{array}$ & $\begin{array}{c}273,000 / 70=3900 \\
\text { USD }\end{array}$ \\
\hline
\end{tabular}

Source: Developed countries (European country) and developing countries (Turkey, Jordan, Armenia, Cambodia) in the appendix list 1 and 2 (Source: Arton Capital (2017), GOCCP (2018), Goldenvisas (2018), Goldencitizenship (2018), author's calculations).

If a citizen from developed countries applies for a developing country passport, the VFC access improves from 150 countries to 157 countries such as Russia, Azerbaijan, Iran, Iraq, Libya, Mongolia, Sudan, Uzbekistan. The average cost of this marginal investment for a developing passport is 150,000 USD divided by 7 countries, (almost) 21,500 USD per VFC. However, unless there is a special case, a developed country citizen rarely needs to visit these countries. However, from a developing country citizen's point of view, through a typical developed country passport acquisition, one jumps from 80 VFC to 150 VFC with 70 countries (including all Europe, Schengen area and big English countries - USA, Canada, Australia, New Zealand and Ireland). The average cost of this marginal improvement is 297,000 USD (average European citizenship cost) divided by 70 countries, (approximately) 3900 USD per country (a far below than 21, 500 USD). Besides, a developing country citizen may expect to visit these countries rather than other developing countries due to business and touristic reasons. China and Russia are the first and second country to apply for the Schengen visa (Etias, 2018)

This marginal analysis also shows that those citizens who already carry powerful passport do not need to have economic citizenship for gaining access to visa-free. 


\section{Investment Threshold Analysis}

In our analysis, we consider the cost as opportunity cost. We assume that there is a financing opportunity. Indeed, in some countries banks promote this scheme (i.e. Bulgaria and Portugal). However, in some cases, one may not find funding opportunities.

Graph 1 shows the initial investment requirements for each country without financing opportunities. The U.K. fast-track Bulgaria and Cyprus require a great deal of financial threshold above 2 million USD. Bulgaria via residency and Malta need 1 million USD but the investment is refunded in Bulgaria after 5 years. In Serbia, the government asks 184,000 USD for donation (plus fees) and U.K. requests 2,800,000 USD investment.

In the case of Serbia, the donation is irrevocable investment however, in the U.K., one may hope for a good return. On the other hand, under the financing constraints, one should opt for Serbia.

\section{Graph 1. Initial Investment Requirements in Europe}

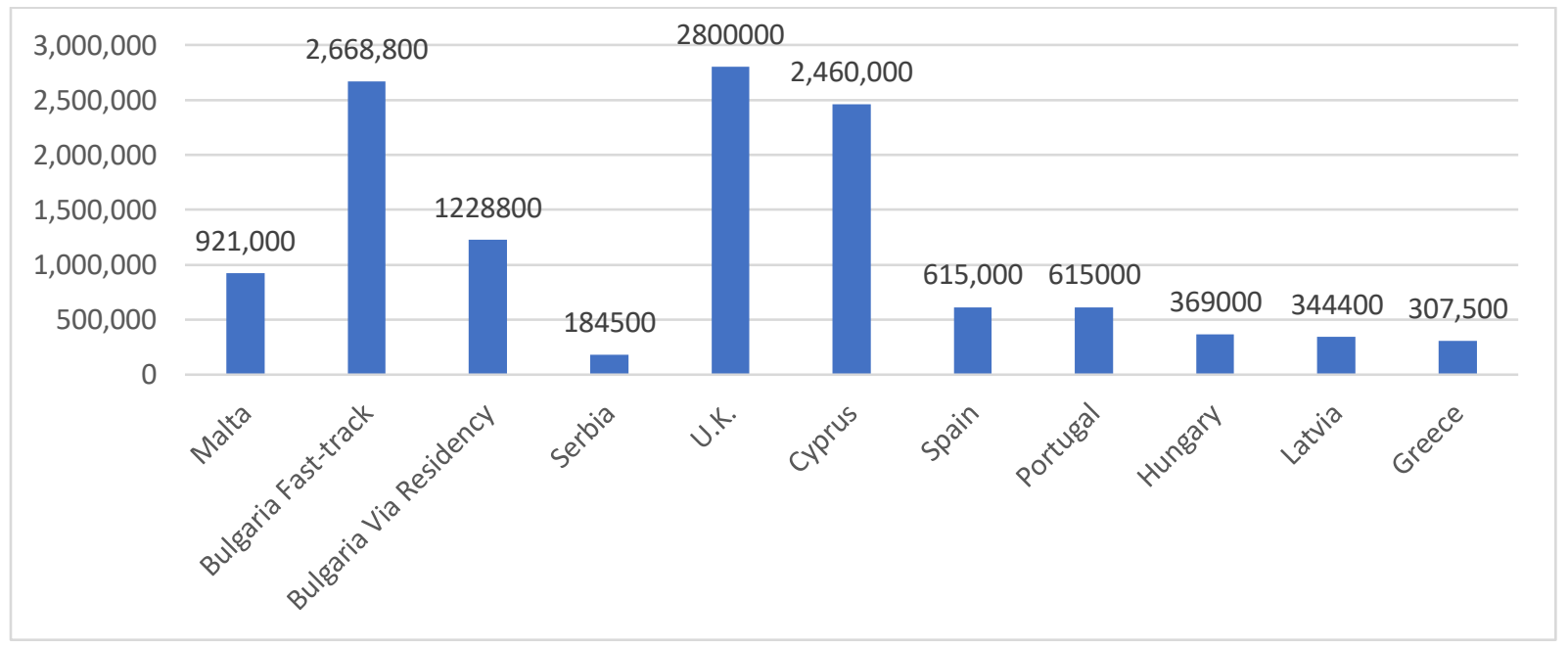

Source: Arton Capital (2018).

\section{Specific Needs}

Indeed, the specific needs would determine which economic citizenship program is the best for an investor. Our analysis is based on two issues cost of acquisition (government charges) and visa-free access-benefits (number VFC)

However, there are some other issues that an individual should consider. 
Being from a particular country: There are restrictions at several countries (e.g. Iran) to some economic citizenship programs (Caribbean countries) due to the U.S. sanctions. Therefore, an Iranian has to consider other citizenship-by-investment programs (i.e., Montenegro, Bulgaria, Malta or Cyprus).

Names are required to change: Although Cambodian passport is not a very strong document for VFC travel (51 VFC), Cambodian citizenship may offer other benefits that can be worth consideration as privacy protection. Investor and his family members can choose a new Khmer name and transfer part of the wealth into the new name. For example, one can use a new Cambodian document for banking.

Visa-free access of a particular country: Among Caribbean countries, although access VFC is very similar, there are slight differences that can be crucial for an applicant. For example, Grenada has visa-free access to Russia and China while Antigua and Barbuda do not have. Therefore, an investor may conduct lots of businesses with Russia/China and may prefer Grenada over Antigua and Barbuda. Economically, the difference between the costs of Grenada and Antigua and Barbuda is 50.000 USD for a family. Is it worthy of having visa-free access to China and Russia for 25.000 USD each? For a touristic purpose, if one person considers entering only one or two times in one's lifetime, probably it is not worthy. Acquiring visa cost from Russia and from China (multiple-entry and issuance within 3 days) is 540 USD and 170 USD, respectively (Russian Embassy, 2018, Chinese Embassy, 2018). But if one needs to visit these countries many times, then the Grenadian citizenship is worthy to consider.

\section{Conclusion and Future of Economic Citizenship}

Recently, many countries have launched their own citizenship by investment program or economic citizenship. This is proof that the trend "economic citizenship" has moved beyond a few Caribbean islands and into both Europe and now the rest of the world. Economic citizenship market is institutionalized and works very well. However, is it worthy for the investment?

We calculate the return of a passport under three analyses: visa-free return, marginal contribution and investment. The return on investment for the visa-free access is very moderate, around $0,3-2 \%$ for a family and $0.2-0.5 \%$ for a single. So, unless, a family or a single travel very often (at least 4 times), it is not worthy based on visa-free access. 
Adding different opportunities such as obtaining EU citizenship and tax advantages, may raise the investment returns. The best deals are Portuguese for a frequent traveler family (1.9\%$3.3 \%$ ) and a frequent traveler single $(0.5 \%-0.9 \%)$ in EU without or very low residency requirement. Serbia through donation offers economic citizenship similar or little more expensive than various Caribbean passports with substantial benefits regarding potential EU citizenship. After Serbia joins the EU, its price deal might match to Bulgarian economic citizenship price.

Among non-EU countries and non-Caribbean countries, Canada and USA have a similar low return (by $0,2 \%$ ) and requires residence for 4- and 5-years residency in the country to obtain citizenship, respectively. Vanuatu has a higher price tag to Caribbean countries but offers a similar benefit. Vanuatu is expected to lower its price.

Under the marginal contribution analysis, we eliminate the redundancy among passports and we calculate the additional benefits of a passport. This shows that acquiring a passport from developing countries is not meaningful for the citizens from developed countries.

Under the investment analysis, we demonstrate the minimum investment requirements for citizenship. Countries such as, the U.K., Cyprus and Bulgaria do not ask for a donation but require around 2 million USD investment. Among the minimum payment criterion, the best deal is from Serbia which requires 150,000 EURO donations. However, we predict that the economic citizenship is enlarging and is becoming an industry, therefore the banking sector will offer many different financing options.

The article focuses on the discussion of the cost of acquisition and visa-free access. However, there are some other issues that an individual should consider: a) being from a particular country: There are restrictions at several countries (e.g. Iran) to some economic citizenship programs (Caribbean countries) due to the U.S. sanction, b) Names are required to change: Investor and his family members can choose a new Khmer name and transfer part of the wealth into the new name. c) Visa-free access of a particular country: there are slight differences of visa-free access (i.e., Russia and China) that can be crucial for an applicant among Caribbean passports. d) visa rejection, time inconsistency, single-entry and location risks during the application: around $8 \%$ of the Schengen visa application is rejected. Additionally, the visa payment fee is non-refundable. 


\section{Reference}

Arton Capital (2018). Quebec, Canada Residency \& Citizenship by Investment [online]. https://www.artoncapital.com/global-citizen-programs/canada-quebec/

Arton Capital. (2017). Second Residency and Second Citizenship Cost [online]. www.artoncapital.com/cost

Bachman, J. (2017). The Most Desirable Passports On Earth Don't Include America's [online]. https://www.bloomberg.com/news/articles/2017-03-03/the-most-desirable-passportson-earth-don-t-include-america

Barkan E.R.\& Khokhlov, N. (1980). Socioeconomic data as indices of naturalization patterns in the United States: A theory revisited. Ethnicity, 7: 159-190.

Beck, Katie (30 May 2017). Why Citizenship Is Now a Commodity [online]. http://www.bbc.com/capital/story/20170530-why-citizenship-is-now-a-commodity

Belize Company. (2018). Economic Citizenship Programme [online]

https://www.belizecompany.com/Regulators-and-Legislation/Economic-CitizenshipProgramme/

Bevelander, P. (2000). Immigrant Employment Integration and Structural Change in Sweden: 1970-1995. Lund Studies in Economic History. Lund: Lund University Press.

Brinker, T and Dalson, A. (2018), "Obtaining Economic Citizenship in the Caribbean: Can “Home” Be Bought?”, Journal Of Practical Estate Planning, April-May, p.21-24.

Bloomberg (2019). US Government Rates. https://www.bloomberg.com/markets/rates-bonds/government-bonds/us

Caribbean and Land Property. (2018). Second Passport \& Economic Citizenship [online]. http://www.caribbeanlandandproperty.com/offshore_company_offshore_banking/econ omic_citizenship.

China Foreign Service. (2018). Visa Fees [online]. http://www.chinaembassy.org/eng/visas/fees/). 
Csglobalpartners. (2018). Second Citizenship Investment [online]. www.csglobalpartners.com

Curshen, J. (2006). Second Passport and Offshore Residency Programs, Royal Soclety Of Fellows Newsletter [online],http://mfsfi nancial.com/royalsocietyoffellowsnewsletter/id6.html.

Dhami, S. (2017), The Foundations of Behavioral Economic Analysis. Cambridge: Oxford University Press.

DeVoretz, D. J. \& Pivnenko. S. (2004), “The Economic Causes and Consequences of Canadian Citizenship", IZA DP No. 1395

Etias. (2018). Schengen Statistics [online]. https://etias.com/about-etias/etias-key-facts

GOCCP (2018). Citizenship and Residency Programs [online]. www.goccp.com

Goldenvisas (2018). Citizenship and Residency Programs [online]. www.goldenvisas.com

Goldencitizenship (2018). Citizenship and Residency Programs [online] www.goldencitizenship.com

Houlder, V. (2016). Citizenship Is For To The Wealthy [online]. https://www.ft.com/content/155936ec-2728-11e6-8ba3-cdd781d02d89

Kelley, J., \& McAllister, I. (1982). The decision to become an Australian citizen.

Australian and New Zealand Journal of Sociology, 18(3): 428-439.

Mazzoları. F. (2009), “Dual Citızenshıp Rights: Do They Make More

And Richer Citızens?”, Demography, 46 (1), 169-191

Henderson, A. (2018), Nomad Capitalist: How to Reclaim Your Freedom with Offshore Bank Accounts, Dual Citizenship, Foreign Companies, and Overseas Investments. Hong Kong: Nomad Books.

Henderson, A. 2017. Nomad Capitalist Flag Theory [online]. www.nomadcapitalist.com

OCCRP. (2018). Bulgaria's Golden Visas Missed Targets and a Banking Loophole [online]. https://www.occrp.org/en/goldforvisas/bulgarias-golden-visas-missed-targets-and-abanking-loophole. 
Mazzolari, F. (2009). Dual Citizenship Rights: Do They Make More and Richer Citizens. Demography, 46 (1), 169-191.

Passport Index. (2018). Passport Index Ranking [online]. https://www.passportindex.org/

St. Kitts \& Nevis Citizenship by Investment Program. (2018). Tax [online].

www.skbfinancialservices.com/citizenship.php.

Portes, A., \& Mozo, R. (1985). The political adaptation process of Cubans and other

ethnic minorities in the United States: A preliminary analysis. International Migration Review, 16 (1): 35-63.

Portes, A., and Curtis, J.W. 1987. Changing flags: Naturaalization and its determinants among Mexican Immigrants. International Migration Review, 21(2): 352-371.

Professional Wealth Magazine (2018). CBI Index. https://www.pwmnet.com/SpecialReports/CBI-Index/CBI-INDEX-REPORTS

Russian Foreign Service. (2018). Russian Visa Fees [online]. http://www.russianembassy.org/page/visa-processing-fees,

St. Kitts \& Nevis and Dominica 2018. Citizenship-by-Investment Programs [online]. https://apexcapital.partners/caribbean/passports-purchase-open-citizenship-doorsaround-world/

Stone, J. (2018). Serbia and Montenegro could join EU by 2025, European Commission says [online]. https://www.independent.co.uk/news/world/europe/eu-enlargement-serbia$\underline{\text { montenegro-macedonia-albania-kosovo-brexit-juncker-2025-a8197201.html }}$

U.S. Immigration Office (2018). EB-5 Requirements [online]. https://www.uscis.gov

Xin X., El-Ashram, A. \& Judith G. (2015), "Too Much of a Good Thing? Prudent Management of Inflows under Economic Citizenship Programs”, IMF Working Paper, WP/15/93

Yang, P.Q. (1994). Explaining immigrant naturalization. International Migration Review, 28(3): 449-477. 


\section{ANNEX}

Table 1: The List of Investment for a Family of Four Based on Opportunity Cost (Europe, Caribbean, Others)

\section{European Countries}

\begin{tabular}{|c|c|c|c|c|c|c|c|}
\hline & $\begin{array}{c}\text { Real } \\
\text { Estate }\end{array}$ & Cash & $\begin{array}{l}\text { State } \\
\text { fee }\end{array}$ & $\begin{array}{c}\text { Professional } \\
\text { fees }\end{array}$ & $\begin{array}{c}\text { Total } \\
\text { opportunity } \\
\text { cost }\end{array}$ & Visa & $\begin{array}{l}\text { Cost } \\
\text { per } \\
\text { VFC }\end{array}$ \\
\hline \multicolumn{8}{|l|}{ Europe } \\
\hline Malta & & 882.625 & 130.525 & 10.000 & 1.023 .150 & 157 & 6517 \\
\hline $\begin{array}{l}\text { Bulgaria Fast- } \\
\text { track }\end{array}$ & & 341.504 & 51.750 & 10.000 & 403.254 & 150 & 2688 \\
\hline $\begin{array}{l}\text { Bulgaria via } \\
\text { Residency }\end{array}$ & & 294400 & 80.500 & 10.000 & 384.900 & 150 & 2566 \\
\hline Serbia & & 172500 & 48.000 & 10000 & 230500 & 119 & 1937 \\
\hline U.K. & & 256000 & 6400 & 10000 & 272400 & 160 & 1703 \\
\hline Cyprus & 207.000 & & 34.500 & 20.000 & 261.500 & 151 & 1732 \\
\hline Spain & 172.500 & & 59.800 & 10.000 & 242.300 & 161 & 1505 \\
\hline Montenegro- & 17250 & & 115000 & 10.000 & 142.250 & 117 & 1216 \\
\hline $\begin{array}{c}\text { Portugal-real } \\
\text { estate }\end{array}$ & 103500 & & 56.350 & 10.000 & 169.850 & 160 & 1062 \\
\hline Hungary & & 60375 & 69000 & 10000 & 139375 & 155 & 899 \\
\hline Latvia & & 64400 & 29900 & 10000 & 104300 & 154 & 677 \\
\hline Greece & 60.375 & & 23.000 & 10.000 & 93.375 & 158 & 591 \\
\hline $\begin{array}{l}\text { Portugal-RE } \\
\text { Fund }\end{array}$ & 24150 & & 56350 & 10.000 & 90.500 & 160 & 566 \\
\hline
\end{tabular}

Source: Arton Capital (2017), GOCCP (2018), Goldenvisas (2018), Goldencitizenship (2018), author's calculations.

Caribbean Countries

\begin{tabular}{|c|c|c|c|c|c|c|c|}
\hline Caribean & $\begin{array}{c}\text { Real } \\
\text { Estate }\end{array}$ & $\begin{array}{l}\text { Cash/Bond/ } \\
\text { Donation }\end{array}$ & $\begin{array}{l}\text { State } \\
\text { fees }\end{array}$ & $\begin{array}{c}\text { Professional } \\
\text { fees }\end{array}$ & $\begin{array}{c}\text { Total } \\
\text { opportunity } \\
\text { cost }\end{array}$ & $\begin{array}{c}\text { Visa } \\
\text { Free } \\
\text { Country }\end{array}$ & $\begin{array}{l}\text { Cost } \\
\text { per } \\
\text { VFC }\end{array}$ \\
\hline $\begin{array}{c}\text { Antigua and } \\
\text { Barbuda } \\
2017\end{array}$ & & 100.000 & 45000 & 10000 & 155.000 & 129 & 1105 \\
\hline $\begin{array}{l}\text { St. Kitts and } \\
\text { Nevis } 2018 \\
\text { (tem) }\end{array}$ & & 150.000 & 11.500 & 10000 & 171.500 & 129 & 1329 \\
\hline $\begin{array}{c}\text { St. Kitts and } \\
\text { Nevis } 2017 \\
\text { (reg) }\end{array}$ & & 195.000 & 11.500 & 10000 & 216.500 & 129 & 1678 \\
\hline St. Lucia & & 190.000 & 16.500 & 10.000 & 216.500 & 125 & 1732 \\
\hline Grenada & & 200.000 & 18.000 & 10.000 & 228.000 & 124 & 1839 \\
\hline $\begin{array}{c}\text { Antigua and } \\
\text { Barbuda } \\
2014 \\
\end{array}$ & & 200.000 & 40000 & 10000 & 250.000 & 129 & 1938 \\
\hline
\end{tabular}




\begin{tabular}{ccccccc}
\hline Dominica & 200.000 & 52.500 & 10.000 & 262.500 & 119 & 2206 \\
\hline $\begin{array}{c}\text { St. Kitts and } \\
\text { Nevis 1990 }\end{array}$ & 300.000 & 136.500 & 10000 & 446.500 & 129 & 3461 \\
\hline
\end{tabular}

Source: Arton Capital (2017), GOCCP (2018), Goldenvisas (2018), Goldencitizenship (2018), author's calculations.

Others (Family and Single)

\begin{tabular}{|c|c|c|c|c|c|c|c|}
\hline Others & $\begin{array}{c}\text { Real } \\
\text { Estate }\end{array}$ & Cash & $\begin{array}{l}\text { State } \\
\text { fee }\end{array}$ & $\begin{array}{l}\text { Professional } \\
\text { fees }\end{array}$ & $\begin{array}{c}\text { Total } \\
\text { opportunity } \\
\text { cost }\end{array}$ & $\begin{array}{c}\text { Visa } \\
\text { Free } \\
\text { Country }\end{array}$ & $\begin{array}{l}\text { Cost } \\
\text { per } \\
\text { VFC }\end{array}$ \\
\hline Panama & & 39000 & 5000 & 10000 & 54000 & 121 & 446 \\
\hline Canada/Quebec & & 225564 & 10000 & 10000 & 245563,9 & 159 & 1544 \\
\hline Cambodia & 28170 & & 5000 & 5000 & 38170 & 53 & 720 \\
\hline $\begin{array}{c}\text { Armenia } \\
\text { (proposed) }\end{array}$ & & 50000 & 10000 & 2000 & 62000 & 62 & 1000 \\
\hline USA & 105000 & & 1000 & 60000 & 166000 & 160 & 1038 \\
\hline $\begin{array}{l}\text { Union of } \\
\text { Comoros } \\
\text { (closed) }\end{array}$ & & 85000 & 5000 & 7500 & 97500 & 52 & 1875 \\
\hline Vanuatu 2017 & & 130.000 & 105.000 & 10.000 & 245.000 & 120 & 2042 \\
\hline $\begin{array}{c}\text { Turkey deposit } \\
2018\end{array}$ & & 30000 & 1000 & 5000 & 36000 & 111 & 324 \\
\hline $\begin{array}{c}\text { Turkey deposit } \\
2017\end{array}$ & & 180000 & 1000 & 5000 & 186000 & 111 & 1676 \\
\hline $\begin{array}{c}\text { Turkey Real } \\
\text { Est. } 2017\end{array}$ & 90000 & & 200000 & 5000 & 205000 & 111 & 1847 \\
\hline $\begin{array}{l}\text { Turkey Real } \\
\text { Est. } 2018\end{array}$ & 22500 & & 50000 & 5000 & 55000 & 111 & 495 \\
\hline Vanuatu 2016 & & 260.000 & 105000 & 10.000 & 375.000 & 120 & 3125 \\
\hline Jordan & & 375000 & 1000 & 2000 & 378000 & 50 & 7560 \\
\hline
\end{tabular}

Source: Arton Capital (2017), GOCCP (2018), Goldenvisas (2018), Goldencitizenship (2018), author's calculations.

Table 2. Cost of Acquisition for Single (Europe, Caribbean, Others)

Europe (Single)

\begin{tabular}{cccccccc}
\hline & $\begin{array}{c}\text { Real } \\
\text { Estate }\end{array}$ & $\begin{array}{c}\text { Cash/Bond/ } \\
\text { Donation }\end{array}$ & $\begin{array}{c}\text { State } \\
\text { fees }\end{array}$ & $\begin{array}{c}\text { Professional } \\
\text { fees }\end{array}$ & $\begin{array}{c}\text { Total } \\
\text { cost }\end{array}$ & $\begin{array}{c}\text { Visa } \\
\text { Free } \\
\text { Country }\end{array}$ & $\begin{array}{c}\text { Cost } \\
\text { per } \\
\text { VFC }\end{array}$ \\
\hline Europe & & & & & & & \\
\hline Malta & & 921.000 & 9.000 & 8.000 & 938.000 & 157 & 5975 \\
\hline U.K. & & 280000 & 5600 & 8000 & 293600 & 160 & 1835 \\
\hline Cyprus & 216.000 & & 24.000 & 15.000 & 255.000 & 151 & 1689 \\
\hline Spain & 180.000 & & 61.200 & 10.000 & 251.200 & 161 & 1560 \\
\hline
\end{tabular}




\begin{tabular}{|c|c|c|c|c|c|c|c|}
\hline Bulgaria Fast-Track & & 190464 & 45.000 & 8.000 & 243.464 & 150 & 1623 \\
\hline $\begin{array}{c}\text { Bulgaria Via } \\
\text { Residency }\end{array}$ & & 153600 & 63.000 & 8.000 & 224.600 & 150 & 1497 \\
\hline Serbia & & 120000 & 24.000 & 8000 & 152000 & 119 & 1277 \\
\hline Portugal & 108000 & & 46.800 & 8.000 & 162.800 & 160 & 1018 \\
\hline Hungary & & 63000 & 48000 & 8000 & 119000 & 155 & 768 \\
\hline Latvia & & 67200 & 30240 & 8000 & 105440 & 154 & 685 \\
\hline Greece & 63.000 & & 22.200 & 10.000 & 95.200 & 158 & 603 \\
\hline
\end{tabular}

Source: Arton Capital (2017), GOCCP (2018), Goldenvisas (2018), Goldencitizenship (2018), author's calculations.

\begin{tabular}{|c|c|c|c|c|c|c|c|}
\hline \multicolumn{8}{|c|}{ Caribbean (Single) } \\
\hline Caribean & $\begin{array}{c}\text { Real } \\
\text { Estate }\end{array}$ & $\begin{array}{l}\text { Cash/Bond/ } \\
\text { Donation }\end{array}$ & $\begin{array}{c}\text { State } \\
\text { fees }\end{array}$ & $\begin{array}{c}\text { Professional } \\
\text { fees }\end{array}$ & Total cost & $\begin{array}{c}\text { Visa } \\
\text { Free } \\
\text { Country }\end{array}$ & $\begin{array}{l}\text { Cost } \\
\text { per } \\
\text { VFC }\end{array}$ \\
\hline St. Lucia & & 100.000 & 9.500 & 8000 & 117.500 & 125 & 940 \\
\hline Dominica & & 100.000 & 10.000 & 8000 & 118.000 & 119 & 992 \\
\hline $\begin{array}{c}\text { Antigua and } \\
\text { Barbuda } \\
2017\end{array}$ & & 100.000 & 33500 & 8000 & 141.500 & 129 & 1097 \\
\hline $\begin{array}{l}\text { St. Kitts and } \\
\text { Nevis } 2018 \\
\text { (tem) }\end{array}$ & & 150.000 & 7.500 & 8000 & 165.500 & 129 & 1283 \\
\hline $\begin{array}{l}\text { St. Kitts and } \\
\text { Nevis 2017 } \\
\text { (reg) }\end{array}$ & & 150.000 & 7.500 & 10000 & 167.500 & 129 & 1298 \\
\hline Grenada & & 150.000 & 8.000 & 8000 & 166.000 & 124 & 1339 \\
\hline $\begin{array}{c}\text { Antigua and } \\
\text { Barbuda } \\
2014\end{array}$ & & 150.000 & 20000 & 8000 & 178.000 & 129 & 1380 \\
\hline $\begin{array}{l}\text { St. Kitts and } \\
\text { Nevis } 1990\end{array}$ & & 300.000 & 136.500 & 10000 & 446.500 & 129 & 3461 \\
\hline
\end{tabular}

Source: Arton Capital (2017), GOCCP (2018), Goldenvisas (2018), Goldencitizenship (2018), author's calculations.

\section{Explanation in Details \\ Europe (Family)}

\begin{tabular}{cl}
\hline Malta & $\begin{array}{l}\text { 650.000 EURO donation, 150.000 EURO bond (5\% foregone earning= 37500E), 80.000E rent } \\
\text { obligation, 113500 EURO State Fee }\end{array}$ \\
\hline Serbia & 150.000 EURO Donation, 40.000 EURO State Fee, \\
\hline U.K. & 2 million POUND for 5 years-return, 5000 POUND State Fee \\
\hline Cyprus & $\begin{array}{l}\text { 2 million EURO real investment (upto 1.5M can be alternative investment) - State Fee 4000 E, } \\
500.00 \text { E real estate (kept forever) }\end{array}$ \\
\hline Spain & 500.000 EURO real estate for 10 years, 10\% property transfer tax \\
\hline
\end{tabular}




\begin{tabular}{cl}
\hline Portugal & $\begin{array}{c}500.000 \text { EURO real estate for 6 years return, 6\% property tax transfer, 0,8\% stamp, 15.000E } \\
\text { processing as State Fees }\end{array}$ \\
\hline Bulgaria & 1 million EURO for 3 years \\
\hline $\begin{array}{c}\text { Hungary } \\
\text { closed) }\end{array}$ & 300,000 EURO bond five years, 60,000 EURO State Fee \\
\hline Montenegro & 250,000 EURO real estate for 2 years, 100,000 EURO state fee \\
\hline Latvia & 280,000 EURO investment for 10 years 26,000 E State Fee \\
\hline Greece & $\begin{array}{c}250.000 \text { EURO real estate for 7 years, 5\% property registration fee, 0,5\% land registration, } \\
\text { 3500 E registration, 500E application }\end{array}$ \\
\hline $\begin{array}{c}\text { Antigua and } \\
\text { Barbuda } \\
\text { (reduced) }\end{array}$ & 100.000 USD donation (reduced), 45,000 USD state fee \\
\hline $\begin{array}{c}\text { Grenada } \\
\text { St.Kitts and } \\
\text { Nevis 1990 }\end{array}$ & 300,000 USD donation, 136,500 state fee \\
\hline $\begin{array}{c}\text { St. Kitts and } \\
\text { Nevis 2017 } \\
\text { (regular) }\end{array}$ & 195,000 USD donation, 11500 USD state fee \\
\hline $\begin{array}{c}\text { St.Kitts and } \\
\text { Nevis 2018 } \\
\text { (Temporarily) }\end{array}$ & 150.000 USD donation, 11500 state Fees \\
\hline Dominica & 200.000 USD donation, 75.000 USD state fee \\
\hline \begin{tabular}{l} 
St. Lucia \\
\hline
\end{tabular} & 190.000 USD donation, 12500 USD state fee, 4000 USD procession fee \\
\hline
\end{tabular}

\begin{tabular}{cl}
\hline & \multicolumn{1}{c}{ Others (Families and singles are the same.) } \\
\hline Vanuatu & 130.000 USD donation, 105.000 State fee \\
\hline Turkey deposit & 500000 USD CD (retrurn 3,5\% tax 0.5\%) \\
\hline Turkey Real Estate & 250,000 USD real estate (3 years) \\
\hline USA & 500,000 USD real estate (for 10 years) \\
\hline Canada/Quebec & $1,200,000$ CAD government bond for 3 years, (return 2\%) \\
\hline Panama & 390,000 USD for 5 years \\
\hline Jordan & $1,500,000$ USD government bond (\% 0 return, for 5 years) \\
\hline Armenia (proposed) & 50,000 USD donation, 10,000USD state fee \\
\hline Cambon of Comoros (closed) & 85,000 USD donation, 5,000 USD state fee \\
\hline
\end{tabular}

\begin{aligned} \hline 1 EURO & 1.15 USD \\ \hline 1 Pound & 1.28 USD \\ \hline 1 USD & 1.33 CAD \\ \hline Opportunity cost & $5 \% \\$\hline Cost & Familly with 2 children \end{aligned}

State Fees All fees taken by government under application, due diligence, processing, certification,...

Source: Arton Capital (2017), GOCCP (2018), Goldenvisas (2018), Goldencitizenship (2018), author's calculations. 